\title{
Microbiological evaluation of acerolas from a private cultivated orchard in the city of Macapá, Amapá, Brazil
}

\author{
Avaliação microbiológica de acerolas provenientes de um pomar de cultivo \\ particular na Cidade de Macapá, Amapá, Brasil
}

\author{
Jaqueline Freitas Souza1, Evanilza Aristides Santana², Anne do Socorro Santos da Silva ${ }^{3}$, \\ Antonio Carlos Freitas Souza
}

\begin{abstract}
${ }^{1}$ Pharmacist, Master's student in Animal Science, State University of Maranhão-UEMA, São Luís-MA Brazil. https://orcid.org/0000-0002-30463212 E-mail: jackllinefn@hotmail.com * Corresponding author

${ }^{2}$ Pharmacist graduated from the Mapacaense Institute of Higher Education-IMMES, Macapá-AP Brazil. E-mail: evasantana@live.com ${ }^{3}$ Nutritionist, Family Health Specialist, Researcher at the Institute of Scientific and Technological Research of the State of Amapá-IEPA, MacapáAP Brazil. E-mail: annedosocorro@hotmail.com

${ }^{4}$ Biologist, Master in Health Sciences, PhD student in Animal Science, Researcher at the Institute of Scientific and Technological Research of the State of Amapá-IEPA, Macapá-AP Brazil. https://orcid.ora/0000-0002-6921-9030 E-mail: jr_bio2005@yahoo.com.br
\end{abstract}

\section{Keywords \\ Quality control \\ Tropical fruit \\ Coliforms \\ Salmonella}

Worldwide, there is a significant increase in the consumption of tropical fruits, due to its characteristics and characteristics, among them acerola (Malpighia emarginata DC.), Where Brazil has a very favorable climate for its culture. The acerola fruits were collected in February 2019 in a private cultivated orchard in the municipality of Macapá-AP. For microbiological analyzes, the determination of total, thermotolerant and Salmonella sp. according to standard techniques in food microbiology. Total and thermotolerant coliforms with values ranging from $2.1 \times 10^{2}$ to $>1.1 \times 10^{3} \mathrm{NMP} / \mathrm{g}$ were found in the samples of acerola in the wild, while salmonella were not identified. With these findings, it was necessary to carry out pasteurization, which caused a $100 \%$ reduction in contamination by microorganisms, leaving it in accordance with current legislation. In the initial microbiological analyzes, high counts of microorganisms were demonstrated, making pasteurization necessary for decontamination, making them fit for consumption.

\section{Palavras-chave}

Controle de qualidade Fruta tropical

Coliformes

Salmonella

\begin{abstract}
No mundo inteiro observa-se um aumento significativo para o consumo de frutas tropicais, devido as suas funcionalidades e propriedades, dentre elas destaca-se a acerola (Malpighia emarginata DC.), onde o Brasil, apresenta um clima bastante favorável para a sua cultura. Os frutos de acerola foram coletados no mês de fevereiro de 2019 em um pomar de cultivo particular no município de Macapá-AP. Para as análises microbiológicas foi realizada a determinação de coliformes totais, termotolerantes e Salmonella sp. de acordo com as técnicas padrões em microbiologia de alimentos. Foram encontrados coliformes totais $e$ termotolerantes com valores variando entre $2,1 \times 10^{2} a>1,1 \times 10^{3} \mathrm{NMP} / \mathrm{g}$, nas amostras de acerola in natura, enquanto que não foram identificadas salmonelas. Com estes achados foi necessária a realização de pasteurização que provocou a redução de 100\% de contaminação por microrganismos, deixando-o de acordo com a legislação vigente. Nas análises microbiológicas iniciais foi demonstrado altas contagens de microrganismos, fazendo-se necessária a pasteurização para a descontaminação, tornando-os aptos para consume.
\end{abstract}

\section{INTRODUCTION}

Worldwide, it is observed a significant increase in the consumption of tropical fruits, due to its functionalities and properties (LIMA, 2010), among which stands out acerola, Malpighia emarginata DC., where Brazil has a very favorable climate for its culture, mainly in the tropical part of the national territory (SOUZA et al., 2006). One of the main advantages of cultivation is the high number of harvests per year, normally four, and can reach seven harvests in the case of irrigated crops (JUNQUEIRA et al., 2004).
Its production normally ranges from 20 to 100 $\mathrm{kg} /$ plant/year, and its fruits usually weigh between 2 and $15 \mathrm{~g}$ and show 1 to $4 \mathrm{~cm}$ in diameter (DELVA; SCHNEIDER, 2013a; NUNES et al., 2011), and in their development phase they show green color and with the arrival of maturation they obtain orange pigments until finally reaching an intense red color when fully ripe, a process that lasts an average of 5 days (BARBOZA; TAVARES; MELO, 1996).

Brazilian industries demand about 34.40 thousand tons of this fruit per year, which is equivalent to $7.16 \%$ of the total of fruits harvested in the country (ALDRIGUE et al., 2002). This 
intense production occurs through the great interest due to its nutritional aspects, which made acerola a highly requested fruit in the world market for the preparation of juices and consumption "in natura" (SOUZA et al., 2006).

The great success of the industrialization of acerola is also due to the amount of edible pulp that the fruit produces, about 70 to $80 \%$ (AGUIAR et al., 2010), given this great productivity it is necessary to obtain a fruit with quality control ideal, allowed for human consumption because it is known that there may be errors in several processes before reaching the consumer's table, resulting in risks (SILVAJUNIOR et al., 2015; SILVA-JUNIOR et al., 2017a; SILVA-JUNIOR et al., 2017b; COSTA; NASCIMENTO; SILVA-JÚNIOR, 2018; JESUS et al., 2018; SILVA-JUNIOR et al., 2018; SOUZA; NASCIMENTO et al., 2019; SOUZA, 2019; SOUZA et al., 2020a; SOUZA et al., 2020b; SOUZA; SOUZA; MENDES, 2020) .

Therefore, the objective of this study was to carry out the microbiological evaluation of aceroleira fruits from a private cultivated orchard in the city of Macapá Amapá.

\section{MATERIAL AND METHODS}

The acerola fruits were collected in February 2019 in a private cultivated orchard in the municipality of Macapá-AP, BR 156, Km 14, branch of Km 9. They were collected directly from the trees, physiologically mature and manually (Figure 1). The process started with the preparation of the pulp through pulping, freezing and pasteurization.

Figure 1. Aceroleira fruit from private cultivation in Macapá.

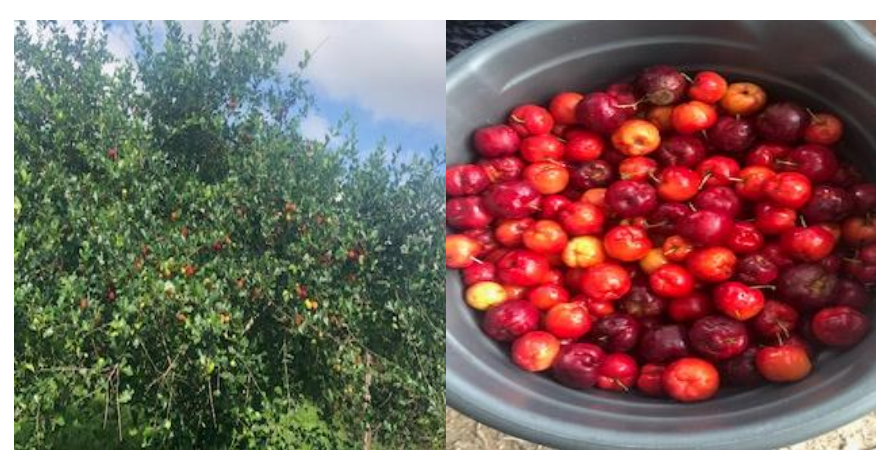

\section{Microbiological analysis}

For the microbiological determinations, aseptic collection of $20 \mathrm{~g}$ of acerola was performed and homogenized in $180 \mathrm{ml}$ of $0.1 \%$ sterile peptone water (HIMEDIA, RM001), with the aid of the homogenizer (Stomacher). Subsequently, the serial dilution of $1 \mathrm{ml}$ of the samples was carried out in $9 \mathrm{ml}$ of the sterile peptone water $0.1 \%$ followed by sowing in plates or tubes for microbiological counts, which were performed in duplicate and according to Brazil (2003) and Silva et al, (2010).
For presumptive analysis of coliforms, three appropriate dilutions of the sample were selected and inoculated into a series of three tubes of lauryl sulfate tryptose broth (LST) (ACUMEDIA, 7142) by dilution, adding $1 \mathrm{ml}$ of the dilution per tube in $10 \mathrm{ml}$ of LST. The tubes were incubated at $37 \pm 1$ 으 / $24 \pm 12 \mathrm{~h}$ and observed if there was growth through turbidity and gas production.

In a positive case, for total coliforms, elevations of the positive tubes were transferred to bright green broth (VB) (KASVI, K25-610010) and incubated at 35으 for 48 hours, and for thermotolerant coliforms, a loaded section of each culture was transferred to tubes of Escherichia coli broth (EC) (ACUMEDIA, 7206) incubated at $42^{\circ} \mathrm{C}$ for $24 \pm 2 \mathrm{~h}$ in a water bath (they remained submerged in water up to a height above the surface of the culture medium) and it was observed growth with gas production.

For the presumptive counting of total and thermotolerant coliforms, the numbers of tubes of Broth EC and Broth VB were recorded and compared with the Most Likely Number table (NMP for decimal dilutions)/g.

To determine the absence/presence of Salmonella sp, 25 $\mathrm{g}$ of each sample was weighed and transferred to a sterile homogenization bag, where $225 \mathrm{ml}$ of buffered peptide water was added. Then the samples were incubated at $37 \pm 1$ 으 for $18 \pm 2$ hours. After incubation, $0.1 \mathrm{ml}$ and $1 \mathrm{ml}$ aliquots were transferred to Rappaport Vassiliadis Soja broths (incubated at $37 \pm 1$ o C / $24 \pm 3 \mathrm{~h}$ ) and Muller Kauffmann Novobiocina Tetrathionate broth (incubated at $41.5 \pm 1$ 으 / $24 \pm 3 \mathrm{~h}$ ) respectively. From the tubes were transferred elevated by streak of exhaustion on the surface of Xylose Lysine Deoxycholate Agar (XLD agar) incubated at $37 \pm 1{ }^{\circ} \mathrm{C} / 24 \pm 3 \mathrm{~h}$.

The confirmation was carried out with the transfer to Triple Sugar Iron agar (TSI) with a deep prick and striated movements on the surface, being incubated at $35 \pm 0.5^{\circ} \mathrm{C} / 18$ 24 hours. After this period, it was passed through a biochemical series (glucose, sucrose and lactose fermentation test; indole test; malonate; citrate; urea; decarboxylation of lysine in broth). The samples that presented biochemical characteristics compatible with the genus Salmonella sp. and those that did not show autoagglutination, were submitted to polyvalent serology.

\section{RESULTS AND DISCUSSION}

\section{Microbiological analysis of acerola, Malpighia emarginata $D C$.}

Total and thermotolerant coliforms with values ranging from $2.1 \times 10^{2}$ to $>1.1 \times 10^{3} \mathrm{NMP} / \mathrm{g}$ were found in the samples of fresh acerola. For thermotolerant coliforms, the values are in disagreement with the resolution RDC № 12 (BRASIL, 2001), 
Table 1. Microbiological analysis of fresh acerola and acerola after pasteurization.

\section{Acerola in natura}

\begin{tabular}{cccc}
\hline Sample & $\begin{array}{c}\text { CTotal } \\
(\mathrm{NMP} / \mathrm{g})\end{array}$ & $\begin{array}{c}\text { Cterm } \\
(\mathrm{NMP} / \mathrm{g})\end{array}$ & Salmonella sp. \\
A1 & $>1,1 \times 10^{3}$ & $>1,1 \times 10^{3}$ & Absent \\
A2 & $>1,1 \times 10^{3}$ & $>1,1 \times 10^{3}$ & Absent \\
A3 & $2,1 \times 10^{2}$ & $2,1 \times 10^{2}$ & Absent \\
\hline Sample & Pasteurized acerola pulp & \\
A1 & CTotal & Cterm & Salmonella sp \\
A2 & $<3$ & $(\mathrm{NMP} / \mathrm{g})$ & Absent \\
A3 & $<3$ & $<3$ & Absent \\
Standard* & $<3$ & $<3$ & Absent \\
Standard** & - & $<3$ & Absent \\
\hline
\end{tabular}

*Brazil (2001); **Brazil (2018)

which establishes a maximum value of $10^{2} \mathrm{NMP} / \mathrm{g}$, whereas for total coliforms, the legislation does not present a parameter, however, this microorganism is an indication of hygienic-sanitary quality, even compared to Normative Instruction No. 49/2018 (BRAZIL,2018) which establishes the identity pattern of fruit juice and pulp, still remain in disagreement. For Salmonella sp. all samples were negative, in accordance with the recommendations of the legislation that determines the absence of $25 \mathrm{~g}$ of sample.

The pasteurization process was carried out in order to decontaminate the fruit, this process caused a $100 \%$ reduction in contamination by microorganisms, leaving the fruit in accordance with both current legislation (BRAZIL, 2011; BRAZIL, 2018), as shown in table 1.

Santini (2017), analyzing frozen fruit pulps acquired in supermarkets in the city of Campinas, SP did not find significant counts of thermotolerant coliforms and Salmonella in the acerola pulps. In the study by Muniz, Reis and Vieira (2017), evaluating samples of frozen fruit pulps where the acquisition was carried out in supermarkets in Southwest Bahia, it was reported that none of the samples of acerola pulps showed growth of total coliforms.

While in the work of Santos and Barros (2012), assessing the health profile of fruit pulps randomly collected at different points of sale in the municipality of Paragominas-PA, found in the analyzes for thermotolerant coliforms pulps of acerola outside the established standard.
For Castro et al. (2015) during the counting of microorganisms, the absence of groups of coliforms and Salmonella sp. in fruit pulps, is directly linked the satisfactory quality of the product, which probably occurs through the appropriate application of storage and/or processing techniques.

According to Siqueira (1995), the total coliform index is used to assess hygienic conditions and the thermotolerant coliform index is adopted as an indicator of faecal contamination. Since high counts mean failures during manufacturing, such as the employees' hygienic-sanitary conditions, poorly washed fruits, poor cleaning and sanitation, inefficient heat treatments and multiplication during the storage process (SOUZA; CARNEIRO; GONSALVES, 2011).

\section{CONCLUSION}

In the initial microbiological analyzes, high counts of microorganisms were demonstrated, making pasteurization necessary for the decontamination of the fruits, meeting the standards established by the current legislation. The findings evidenced the need for a technique to eliminate microorganisms before consumption, as it may bring about a risk to the health of those who choose to consume the fruit in 
natura.

\section{REFERÊNCIAS}

AGUIAR, T. M.; RODRIGUES, F. S.; SANTOS, E. R.; SABAA-SRUR, A. U. O. Caracterização química e avaliação do valor nutritivo de sementes de acerola. Revista da sociedade brasileira de alimentação e nutrição, v. 35, n. 2, p. 91-102, ago. 2010.

BARBOZA, S. B. S. C.; TAVARES, E. D.; MelO, M. B. de. Instruções para o cultivo da acerola. Aracaju: EMBRAPACPATC, 1996. 42p. (EMBRAPA-CPATC. Circular Técnica. 6).

BRASIL, Ministério da Agricultura, Pecuária e Abastecimento. Decreto no 6.871, de 14 de junho de 2001. Padronização, a classificação, o registro, a inspeção e a fiscalização da produção e do comércio de bebidas. Diário Oficial da União. Poder executivo, Brasília, DF, 2001.

BRASIL. Ministério da Agricultura, Pecuária e Abastecimento 2018. Instrução normativa. Métodos físico-químicos para análises de alimentos. Ministério da saúde, Agência nacional de Vigilância Sanitária. IV ed. Instituto Adolfo Lutz. Brasília: Ministério da Saúde, 2018. 1018 p. ISBN 85334-1038-7.

BRASIL. Ministério da Agricultura, Pecuária e Abastecimento. Instrução normativa no 6.982, de 30 de agosto de 2011. Regulamenta a Lei no 8.918, de 14 de julho de 1994, dispõe sobre a padronização, a classificação, o registro, a inspeção, a produção e a fiscalização de bebidas. Diário Oficial da União. 31/08/2011. Seção 1.Disponível em: <https://www.agricultura.gov.br/Instruçãodecreto/d6871 .htm>. Acessado 30 de out de. 2019.

BRASIL. Presidência da República Casa Civil. Decreto no 6.871, de 4 de junho de 2003. Dispõe sobre a padronização, a classificação, o registro, a inspeção, a produção e a fiscalização de bebidas. Diário oficial da Republica do Brasil, Brasilia, DF, Diário Oficial da República Federativa do Brasil 121 de 04.06.2003, seção 1, pág. 20.Disponível em

http://www.planalto.gov.br/ccivil_03/_Ato20072010/200 9/Decreto/D6871.htm acessado em: 01 jul. 2018.

CASTRO, T.M.N.; ZAMBONI, P.V.; DOVADONI, S.; CUNHA NETO, A.; RODRIGUES, L.J. Parâmetros de qualidade de polpas de frutas congeladas. Revista do Instituto Adolfo Lutz. V.74, n.4, p. 426-436, 2015.CERVBRASIL - Associação Brasileira da Indústria da Cerveja. Anuário, 2016. Disponível em: http://www.cervbrasil.org.br/novo_site/anuario/ Acessado em: 20 ago. 2018.

COSTA, A. L. P.; NASCISMENTO, J. F.; SILVA-JÚNIOR, A. C. S. Perfil de resistência de Staphylococcus aureus isolados de pescada amarela (Cynoscion acoupa) comercializada em feira pública. PubVet. v.12, n.5, a84, p.1-6, 2018.

DELVA, L.; SCHNEIDER, R. G. Acerola (Malpighia emarginata $\mathrm{DC})$ : production, postharvest handling, nutrition, and biological activity. Food Reviews International, v. 29, n. 2, p. 107-126, 2013a.

JESUS, L. M. S.; BRITO, R. S.; NASCIMENTO, J. F.; VIEIRA, T. R.; SOARES, N. R. M.; SILVA-JÚNIOR, A. C. S. Avaliação microbiológica do açaí comercializado no bairro Santa Rita, Macapá-Amapá. Revista Arquivos Científicos (IMMES). v. 1, n. 2, p. 21-27, 2018.

JUNQUEIRA, K.P.; PIO, R.; do VALE, M.R.; RAMOS, J.D. CULTURA DA ACEROLEIRA (Malpiglia glabra L.). Lavra: UFLA, 2004. 27p

LEFFA, D. D. et al. Corrective effects of acerola (Malpighia emarginata DC.) juice intake on biochemical and genotoxical parameters in mice fed on a high-fat diet. Mutation Research - Fundamental and Molecular Mechanisms of Mutagenesis, v. 770, p. 144-152, 2014.

LIMA R.M.T. Avaliação da estabilidade química, físico-química e microbiológica de polpas de acerola orgânica pasteurizada e não-pasteurizada. [dissertação]. Fortaleza (CE): Mestrado em Ciência e Tecnologia de Alimentos: Universidade Federal do Ceará; 2010. 94p.

MUNIZ, B.C.M; REIS, R.B.S; VIEIRA, V.F. Coliformes Totais e Escherichia coli em Polpas de Frutas Comercializadas no Sudoeste da Bahia. Revista multidisciplinar e de psicologia. v.11, n. 35, p.8, 2017.

NASCIMENTO, J. F.; BARROSO, B. S.; COSTA, A. L. P.; SILVAJÚNIOR, A. C. S. Avaliação microbiológica do Apaiari, Astronotus ocellatus (Agassiz, 1729) (Pisces, Cichlidae) comercializados na Feira do Pescado, Macapá-Amapá. Biota Amazônia. v. 9, n. 2, p. 47-50, 2019.

NUNES, R. S. et al. Antigenotoxicity and antioxidant activity of acerola fruit (Malpighia glabra L.) at two stages of ripeness. Plant Foods for Human Nutrition, v. 66, n. 2, p. 129-135, 2011.

SANTINI, T. P. J. Salmonella sp. e Escherichia coli patogênica em polpas de frutas congeladas e frutas minimamente processadas: ocorrência e susceptibilidade aos agentes antimicrobianos. 2017. Dissertação (Mestrado em Ciência de Alimentos) Universidade Estadual de Campinas, São Paulo. 2017.

SANTOS, D. P; BARROS, B. C. V. Perfil higiênico sanitário de polpas de frutas produzidas em comunidade rural e oferecidas à alimentação escolar. Revista Brasileira de Tecnologia Agroindustrial, v.6, n.2, p.747-756, 2012.

SILVA, N. da; JUNQUEIRA, V.; SILVEIRA, N. F. A.; TANIWAKI, M. H.; SANTOS, R. F.S. dos, GOMES, R. A. R. Manual de métodos de análise microbiológica de alimentos e água. 4 ed. São Paulo: Livraria Varela, 2010. 
SILVA-JÚNIOR, A. C. S.; MALCHER, E. S. T.; SILVA, A. S. S.; NASCIMENTO, J. F.; BARROSO, B. S. Perfil de resistência a antimicrobianos de Staphylococcus aureus isolados de queijo manteiga comercializado em feira pública da cidade de Macapá, AP. Higiene Alimentar. v.31, n. 274/275, p.115119, 2017a.

SILVA-JÚNIOR, A. C. S.; NASCIMENTO, J. F.; TOSTES, E. S. L.; SILVA, A. S. S. Análises microbiológicas de carne bovina moída comercializada em supermercados em Macapá, Amapá. PubVet. v.12, n.10, a199, p.1-7, 2018.

SILVA-JÚNIOR, A. C. S.; SILVA, A. S. S.; BRITO, T. P.; FERREIRA, L. R. Ocorrência de Staphylococcus coagulase positiva e coliformes termotolerantes em Jaraqui, Semaprochilodus brama (Valenciennes, 1850) comercializado na Feira do Pescado, Macapá-AP. Biota Amazônia. v. 5, n. 1, p. 32-36, 2015.

SILVA-JÚNIOR, A. C. S.; SILVA, A. S. S.; SOARES, N. R. M.; MORAES, G. R.; SOUSA, C. M.; NASCIMENTO, J. F. Caracterização físico-química e avaliação microbiológica de concentrado proteico de peixe (Piracuí) comercializado em feiras livres da Cidade de Macapá-AP. Biota Amazônia. v. 7, n. 3, p. 33-36, 2017b.

SIQUEIRA, R. S. Manual de Microbiologia dos Alimentos. EMBRAPA. Centro Nacional de Pesquisa de Tecnologia Agroindustrial de Alimentos. Rio de Janeiro, p. 73-130. 1995.

SOUZA M.J.H; GUIMARÃES M.C.A; GUIMARÃES C.D.L; FREITAS W.S; OLIVEIRA A.M.S. Potencial agroclimático para a cultura da acerola no estado de Minas Gerais. Revista Brasileira de Engenharia Agrícola e Ambiental, v.10, n.2, p.390-396, 2006.

SOUZA, A. C. F.; SOARES, N. R. M.; PAIVA, A. D. C.; SOUZA, J. F.; MENDES, J. T. R. Avaliação microscópica e microbiológica de farinhas de mandioca, Manihot esculenta Crantz, comercializadas nas feiras do produtor e do agricultor na cidade de Macapá, Amapá. Journal of Biology \& Pharmacy and Agricultural Management, v. 16, n. 2, p.122-136, 2020a.

SOUZA, A. C. F.; SOUZA, J. F. Avaliação microbiológica da água de coco-verde (Cocos nucifera L.) comercializada nos quiosques da Praça do Coco, Cidade de Macapá-Amapá. Biota Amazônia. v. 9, n. 3, p. 57-58, 2019.

SOUZA, A. C. F.; SOUZA, J. F.; MENDES, I. G. Avaliação microbiológica de polpas congeladas de frutas comercializadas em feiras públicas da cidade de Macapá, Amapá. Research, Society and Development, v. 9, n. 2, e191922152, p.1-10, 2020.

SOUZA, A. C. F.; VIANA, D. C.; SOUZA, J. F.; COSTA, A. L. P. Análises físico-químicas e microbiológicas da carne moída comercializada em açougues de três bairros da Zona Sul de Macapá - Amapá. Research, Society and Development, v.
9, n. 3, e182932708, P.1-17, 2020b.

SOUZA, G.C.; CARNEIRO, J.G.; GONSALVES, H.R.O. Qualidade microbiológica de polpas de frutas congeladas produzidas no município de russas - CE. ACSA - Agropecuária Científica no Semi-Árido. v. 7, n. 3, p. 01 - 05, 2011.

Submissão: 06/01/2020

Aprovado para publicação: $25 / 03 / 2020$ 